\title{
Surveillance and Control of Invasive Aedes Species in The Eastern Black Sea Area of Turkey
}

\author{
Türkiyenin Doğu Karadeniz Bölgesi’nde istilacı Aedes türlerinin \\ izlenmesi ve kontrolü
}

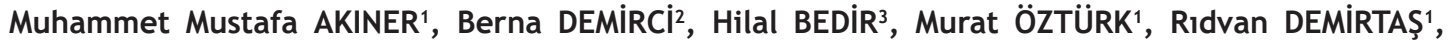
Ahmet Ferhat DOĞAN ${ }^{4}$, Akgün GÖKDEMIR ${ }^{5}$, Seher TOPLUOĞLU ${ }^{6}$, Ünal ALTUĞ ${ }^{6}$, Zehra Özlem KURTCEBE ${ }^{6}$, Hasan IRMAK ${ }^{7}$
\end{abstract}

\begin{abstract}
Objective: Invasive mosquito species are a huge problem world-wide and can cause serious mosquito borne disease epidemics. Recent surveys in Europe revealed that many autocthonous cases of chikungunya are related to the invasive Aedes albopictus and Aedes aegypti species. Extensive surveillance of these species and other invasive Aedine mosquito species is required for the prevention and timely response to possible outbreaks. This study focuses on surveillance and control operation success in the Eastern Black Sea region of Turkey.

Methods: This surveillance study was performed during the 2016-2017 vector active season. Three cities were surveyed according to ECDC and CDC guidelines. Control operations were performed during the second half of the 2017 active season under the supervision of the Turkish Ministry of Health's Zoonotic and Vectorborne Diseases Department. IGR, a Bti/Bs mix and liquid Bti were used for larval control. Different pyrethroids, nicotine mimics and natural products were used for
\end{abstract}

\section{ÖZET}

Amaç: İstilacı sivrisinek türleri tüm kıtalarda büyük problem olup birçok alanda sivrisinek kökenli ciddi hastalık salgınlarına neden olabilmektedir. Avrupa Kıtasındaki son araștırmalar, pek çok otonom chikungunya vakalarının, istilacı Aedes albopictus ve Aedes aegypti türleri ile ilișkili olduğunu göstermiștir. $\mathrm{Bu}$ türlerin ve diğer istilacı Aedine sivrisinek türlerinin kapsamlı șekilde izlenmesi, muhtemel salgınları önlemek ve zamanında müdahale etmek için gereklidir. Bu çalıșma, Doğu Karadeniz bölgesinde izleme ve kontrol çalıșmalarının bașarısı üzerine odaklanmıștır.

Yöntem: İzleme çalıșması 2016-2017 vektör aktif sezonda ve üç şehirde ECDC ve CDC yönergelerine göre gerçekleștirilmiștir. Kontrol çalıșmaları, 2017 vektör aktif sezonun ikinci yarısında T.C. Sağlık Bakanlığı Zoonotik ve Vektörel Hastalıklar Dairesi denetimi altında gerçekleștirilmiștir. Larva kontrolü için IGR, Bti/ Bs karıșımı ile sıvı Bti kullanıımıștır. Ergin kontrolü için farklı pyrethroidler, nikotini taklit eden maddeler ve doğal ürünler kullanılmıștır. Popülasyon dalgalanmaları

'Recep Tayyip Erdogan University, Faculty of Arts and Sciences, Department of Biology, Rize

${ }^{2}$ Kafkas University, Faculty of Arts and Sciences, Molecular Biology and Genetics Department, Kars

${ }^{3}$ Kafkas University, Faculty of Medicine, Medical Parasitology Department, Kars

${ }^{4}$ Turkish Ministry of Health, Provincial Health Directorate, Rize

${ }^{5}$ Turkish Ministry of Health, Provincial Health Directorate, Artvin

${ }^{6}$ General Directorate of Public Health, Zoonotic and Vector-Borne Diseases Department, Ankara

${ }^{7}$ General Directorate of Public Health, Ankara

İletişim/Corresponding Author: Muhammet Mustafa AKINER

RTE Üni. Fen Edebiyat Fak.Biyoloji Bölümü Zihni Derin Kampüsü, Fener 53100 Rize - Türkiye Geliş Tarihi/ Received : 16.02 .2018

Tel : +905342641242 E-posta/E-mail : akiner.m@gmail.com

DOI ID : 10.5505/TurkHijyen.2018.68736

Akıner MM, Demirci B, Bedir H, Öztürk M, Demirtaș R, Doğan AF, Gökdemir A, Topluoğlu S, Altuğ Ü, Kurtcebe ZÖ, Irmak H. Surveillance and control of invasive Aedes species in the Eastern Black Sea area of Turkey. Turk Hij Den Biyol Derg, 2018; 75(3): 225-238 
adult control. Six areas of Ae. albopictus and four areas of Ae. aegypti were selected for assessment of population fluctuations and control operations success.

Results: Twenty-two widely established and two locally established Ae. albopictus populations were detected in 2016. Four widely established and ten locally established Ae. aegypti populations were detected in that the same year. In 2017, 544 potential larval breeding sites were tested in three cities. Persistent infestations of Ae. albopictus were discovered in 194 of these locations. Ae. aegypti was detected in only 25 locations throughout the area. Population densities fluctuated during the season with two population peaks (June-minor, September-major) of Ae. albopictus in 2016. In contrast, population peaks were seen in August and October in Ae. aegypti. The average larval control success was $69 \%$, but adult control success was only $46 \%$ for all areas throughout the season for Ae. albopictus. Similar results were observed for Ae. aegypti, with larval control success at $61 \%$ and adult control success at $37 \%$ after control operations were performed.

Conclusion: The study revealed the persistent rapid expansion and high population density of two invasive mosquito species in the infested areas. Control success was achieved at over $60 \%$ for larvae and around $40 \%$ for adults despite the limited time of this study. The low level of control operation success may be explained by many factors, but the principal factors are the geographical features of the region, climatic variations and restrictions on insecticide usage in tea plantation areas. Therefore, an urgent strategic plan is essential for integrated control strategies.

Key Words: Aedes albopictus, Aedes aegypti, invasive mosquitoes, surveillance, population fluctuations, vector control ve kontrol çalıșmalarının bașarısının değerlendirilmesi amacıyla Ae. albopictus için altı, Ae. aegypti için dört bölge seçilmiștir.

Bulgular: 2016 yılında yirmi iki yaygın ve iki yerel yerleșik Ae. albopictus popülasyonu saptanmıștır. 2016 yılında yaygın oranda yerleșik Ae. aegypti popülasyonu dört noktada, yerel yerleșik popülasyon on noktada bulunmuștur. 2017 yılında üç șehirde 544 muhtemel larva gelișim alanı kontrol edilmiș, 194 noktanın Ae. albopictus tarafından istila edildiği ve kalıcı olarak yer aldığı bulunmuş, Ae. aegypti ise tüm alanda 25 noktada bulunmuștur. 2016 yılında Ae. albopictus popülasyon yoğunlukları sezon boyunca dalgalanmıș ve iki pik yapmıștır (Haziran'da küçük, Eylül'de büyük). $\mathrm{Bu}$ durumun aksine Ae. aegypti pikleri Ağustos ve Ekim aylarında görülmüștür. Tüm sezon boyunca tüm alanlarda Ae. albopictus için ortalama larva kontrol bașarısı \%69 fakat ergin kontrol bașarısı \%46 oranında bulunmuștur. Ae. aegypti için de hemen hemen benzer bir durum gözlenmiștir. Kontrol çalıșmalarından sonra larva kontrol bașarısı \%61, ergin kontrol bașarısı \%37 oranında bulunmuștur.

Sonuç: Çalıșma, istila bölgesinde istilacı iki türün kalıcı, hızlı yayılma biçimi gösterdiğini ve yüksek populasyon yoğunluklu olduğunu göstermiștir. Kontrol çalıșmaları kısıtlı bir zaman periyodu içinde olsa da bașarı oranı larva için \%60'ın üzerinde, ergin için \%40 civarında bulunmuştur. Kontrol başarısının düșük seviyede kalmas pek çok nedenle açıklanabilirse de ana faktörler, alanın coğrafik yapısı, iklimsel çeșitliliği ve çay ekim alanlarında kısıtlı insektisit kullanımıdır. Bu nedenle entegre vektör mücadelesi için acilen stratejik plan yapılması gereklidir.

Anahtar Kelimeler: Aedes albopictus, Aedes aegypti, istilacı sivrisinekler, izleme, popülasyon dalgalanması, vektör kontrolü 


\section{INTRODUCTION}

Invasive mosquito species are defined by their potentiality to be introduced into and rapidly colonize new areas beyond their native territory. Generally, they are the cause of harmful effects on the environment, the economy and the health of animals or humans. Human movement and international trade facilities are the main reasons for their introduction to new areas. These invasive mosquito species are well adapted to dwelling amongst human settlements and buildings where they have access to abundant sources of host blood, resting places and larval breeding sites (1). The invasive Aedes species introduction to Europe is a well-known story; this invasion started with the Asian tiger mosquito (Ae. albopictus) in Albania in 1979 (2), and it was discovered in Italy in the 1990s (3). To date, Ae. albopictus has colonized almost all Mediterranean countries and many central European countries (4). The first recorded discovery of this species in Turkey was in 2011 in the Thrace region (5). By 2015, established populations were in the Eastern Black Sea region (6). The Asian bush mosquito, Aedes japonicus, is spreading in some Central European countries. Aedes atropalpus and Aedes koreicus have been introduced to limited areas in Europe (1). Ae. aegypti was established in Europe during the $17^{\text {th }}-19^{\text {th }}$ centuries, but during the second half of the $20^{\text {th }}$ century, it disappeared in southern Europe. This species has since returned to Europe and established populations are located in Madeira, Russia, Abkhazia and Georgia1. Recently, established populations were discovered on the eastern coast of the Black Sea in Turkey (6).

Ae. albopictus (Skuse, 1894) (Diptera: Culicidae) is a competent vector of grave arboviral infections including dengue fever, yellow fever, chikungunya, and Zika (7-10). There have been many studies made about the rapid expansion of Ae. albopictus (6, 11, 12). This species has rapidly spread from native tropical and subtropical areas of Southeast Asia to Europe, Africa, America, and Australia in a few decades of the $20^{\text {th }}$ century although the normal dispersal ability is only around 800-900 meters (1315).

Ae. aegypti is commonly known as the yellow fever mosquito and is a vector of dengue, chikungunya and Zika virus diseases. It originated from Africa and has two genetically distinct forms: Ae. aegypti formosus, the zoophilic tree hole mosquito, and Ae. Aegypti, the domestic form (16-17). Ae. aegypti has spread from Africa to tropical and subtropical regions of the World (17). It was detected in Europe, especially along the Mediterranean coast, in the first half of the $20^{\text {th }}$ century, but it disappeared from continental Europe after World War II (6). It recolonized on Madeira Island, in the southern part of Russia, and in Georgia after five or six decades, and it has recently been reported in the Netherlands (18-19). In 2015, it was discovered on the Eastern Black Sea coast of Turkey with an expanding east-west pattern from Georgia to Turkey (6). Due to intense commercial and passenger flux, the World Health Organization (WHO) and the European Centre for Disease Prevention and Control (ECDC) have recommended the implementation of vector control measures and surveillance facilities to hinder the vector's expansion throughout the continent (20-21).

Recent surveys of invasive mosquitoes indicate that the Ae. aegypti and Ae. albopictus are the most prevalent species in Europe (22). These two species are able to transmit chikungunya, Zika virus and dengue fever; none of which have a specific cure or vaccine. Furthermore, Ae. albopictus is a bridging vector between animals and humans for some pathogens (23). Therefore, efficient vector control strategies and operations are important tools for the prevention of these diseases and possible epidemics.

In Turkey, mosquito control activities started in the first years of the Republic in 1925 with antilarval operations together with malaria control campaigns. There is no information about mosquito control activities from 1930-1945. Through the years, numerous larvicides and adulticides have 
been used for mosquito control in Turkey. DDT was first introduced as residual spraying in 1946; hereby, chemical control activities began in Turkey (24). Mosquito control activities have been conducted by the Turkish Ministry of Health, municipalities (particularly Culex pipiens control in and around cities), and by private companies in touristic areas.

This study aimed to report the surveillance of two invasive mosquito species during the active seasons of 2016-17 and to assess the mosquito control operations in the Eastern Black Sea region in the same period.

\section{MATERIAL and METHOD}

The entire Middle and Eastern Black Sea region was surveyed from Sarp, a village which is an entry point from Georgia, to the Amasya Province for invasive mosquito species during the active vector season (from May to October) in 2016. Study and control areas were comprised of three cities which were selected according to the surveillance study. All three cities are located in Turkey (Artvin, Rize and
Trabzon Provinces and Districts) near the Georgian border (Fig. 1). Possible larval habitats were checked biweekly in order to determine vector presence, persistence, and spread from June through October.

An active surveillance study was conducted in 2016-17 and different collection techniques were used (larval searches with a larval dipper and human landing catches by mouth aspirator for adults) according to ECDC ${ }^{1}$ and CDC (Center for Disease Control and Prevention) (25) guidelines. For larval collections, the same used tires were utilized each time for larvae collection, and for adult collections, individuals remained in the same location for the human landing catches. First, used tire storage areas and their surrounding areas were checked. Secondly, thrown used tires or waste tires used for various purposes which can create larval breeding areas (man-made containers) were inspected for larvae. Thirdly, cemeteries and their surrounding areas were examined. Larval collection was performed with larval dippers and a count consisted of the total larvae for three dips. Human landing catches were conducted a

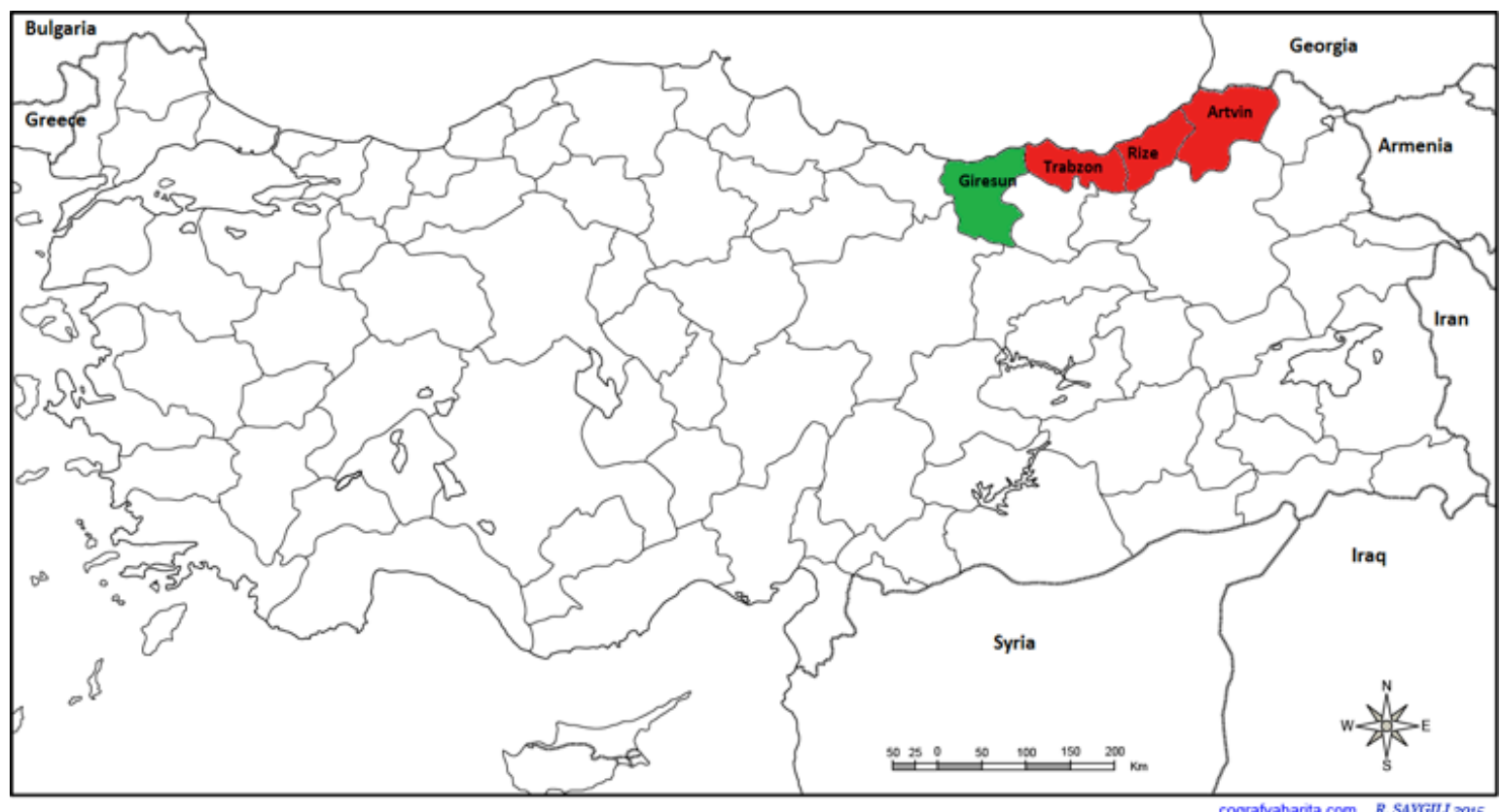

Figure 1. Study and control operations areas during the 2016-17 active vector seasons 
period of ten minutes per individual. All three cities were examined throughout the months for vector spread and the presence of colonized populations. Population count studies were conducted to assess abundance and in order to determine the usage, application frequency, and effectiveness of different control agents. Six locations for Ae. albopictus and four locations for Ae. aegypti were surveyed for this purpose. These population counts were conducted for two years.

Control operations began during the third week of July and different control agents were used for this purpose. Control operations started with larvae control and adulticides were used if the adult density was high in an operational area. The utilized insecticides are listed on Table 1. Insecticide usage profiles and

Table 1. Utilized insecticides during control operations by area

\begin{tabular}{|c|c|c|c|c|}
\hline \multirow{9}{*}{$\sum_{\frac{1}{2}}^{\frac{5}{2}}$} & Insecticide/month & July & August & September \\
\hline & Pyriproxyfen Briquet 10\% & $x$ & & \\
\hline & Bti+Bs Granule 50 BS ITU/mg & & $x$ & \\
\hline & Bti liquid 1200 ITU & & $x$ & $x$ \\
\hline & Geraniol $19 \%$ & $x$ & $x$ & \\
\hline & Cypermethrin 10\%+Tetramethrin 2\%+PBO 10\% & $x$ & & $x$ \\
\hline & Lambda cyhalothrin 5\%+Imidaclobrid $20 \%$ & & $x$ & $x$ \\
\hline & Cypermethrin 35\%+Tetramethrin 5\%+PBO 15\% & & $x$ & $x$ \\
\hline & Cyfluthrin 10\%+Tetramethrin 5\%+PBO $10 \%$ & & & $x$ \\
\hline \multirow{9}{*}{$\frac{N}{\alpha}$} & Insecticide/month & July & August & September \\
\hline & Pyriproxyfen Briquet 10\% & $x$ & & \\
\hline & Bti+Bs Granule 50 BS ITU/mg & & $x$ & \\
\hline & Bti liquid 1200 ITU & & $x$ & $x$ \\
\hline & Geraniol $19 \%$ & $x$ & $x$ & \\
\hline & Cypermethrin 10\%Tetramethrin 2\%+PBO 10\% & $x$ & & $x$ \\
\hline & Lambda cyhalothrin $5 \%+$ Imidaclobrid $20 \%$ & & & $x$ \\
\hline & Cypermethrin 35\%+Tetramethrin 5\%+PBO 15\% & & $x$ & $\mathrm{x}$ \\
\hline & Cyfluthrin 10\%+Tetramethrin 5\%+PBO 10\% & & & $x$ \\
\hline \multirow{9}{*}{ 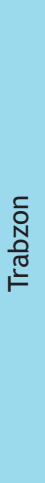 } & Insecticide/month & July & August & September \\
\hline & Pyriproxyfen Briquet 10\% & $x$ & & \\
\hline & Bti+Bs Granule 50 BS ITU/mg & & $x$ & \\
\hline & Bti liquid 1200 ITU & & $x$ & $\mathrm{x}$ \\
\hline & Geraniol 19\% & $x$ & $x$ & \\
\hline & Cypermethrin 10\%Tetramethrin 2\%+PBO 10\% & $x$ & & $x$ \\
\hline & Lambda cyhalothrin 5\%+Imidaclobrid 20\% & & & $x$ \\
\hline & Cypermethrin 35\%+Tetramethrin 5\%+PBO 15\% & & $x$ & $x$ \\
\hline & Cyfluthrin 10\%+Tetramethrin 5\%+PBO 10\% & & & $x$ \\
\hline
\end{tabular}


frequencies were determined according to area count results and whether or not adults were present.

\section{RESULTS}

Established populations of Ae. albopictus and Ae. aegypti were first detected in September 2015 during a surveillance study. Twelve established populations of Ae. albopictus and Ae. aegypti were identified within the area from the Georgian border to the Giresun Province border. These established populations were detected in eight villages or towns within that area (Artvin, Borçka, Hopa, Kemalpașa, Arhavi, Fındıklı, Pazar, and Vakfıkebir) (Unpublished data).

Widely established Ae. albopictus populations were detected in 22 locations of the area during a surveillance study in 2016 and last spread point in the expansion was Espiye in the Giresun province. Furthermore, every possible larval breeding site in Kemalpaşa, Hopa, Arhavi, Borçka, and Fındıklı districts was determined. Two locally established populations in Trabzon city were identified in 2016. Widely established populations of Ae. aegypti were detected in four locations: Hopa, Fındıklı, Pazar and Ardeșen. Additionally, ten locally established populations were identified in 2016. The last spread point of their expansion was discovered in an industrial area of Trabzon.

In 2017, within the Artvin Province, 217 possible larval breeding sites were inspected. It was found that Ae. albopictus had widely distributed into the Artvin city center, as well as in the Borçka, Hopa, Kemalpașa, Sarp, Arhavi districts and their villages within the Artvin Province (a total of 87 locations) by the first week of June. In the Rize Province, 200 possible larval breeding sites were inspected. Established populations were found in 60 areas. As in Artvin, the same situation was discovered in the Rize Province. Ae. albopictus had widely established in Fındıklı, Ardeșen, Çamlıhemșin, Pazar, Derepazarı and the Çayeli city center. Widely established populations were ascertained in Çamlıhemșin, Çayeli, the Rize city center and Derepazarı areas, although the initial detection of the Ae. albopictus in these cities and villages was in 2017. The Trabzon district has three focal points and widely established populations were found in all three areas. In June, 127 areas were inspected and established populations were found in 47 of these. Ae. aegypti was discovered in only 25 locations throughout the area and persisted in 10 locations.

Population counts were performed in 2016-17. The results of the population densities varied widely (Fig. 2). Population densities increased in June and slowly decreased in July. In August, larval densities decreased in the first and third weeks of August but increased again during September. In October, densities decreased, almost reaching zero. Adult densities showed a similar trend. Populations showed a small peak in June and large peak in September.

The highest larval and adult densities were ascertained in Borçka and the second highest were found in Pazar (Fig. 3). In 2017, the larval densities in the areas were found to be approximately one and a half to twofold higher than those of 2016; the same was discovered with adult densities. Borçka and Pazar larval densities were higher than those of other areas. June and July larval densities were approximately at the same levels prior to control operations. In the third week of June, vector control operations commenced with the application of larvicides and adulticides. The decrease in larval densities varied 55\%-82\% when compared to 2016. The decrease in adult densities varied 17\%-94\% when compared to 2016. Average larval control success was $69 \%$, and adult control operations success was $46 \%$ for all areas throughout the season.

Population densities for Ae. aegypti were found to be lower than those of Ae. albopictus in 2016. Larval densities increased gradually from June through August but decreased in September (Fig. 4). In October, the densities increased again. Adult 


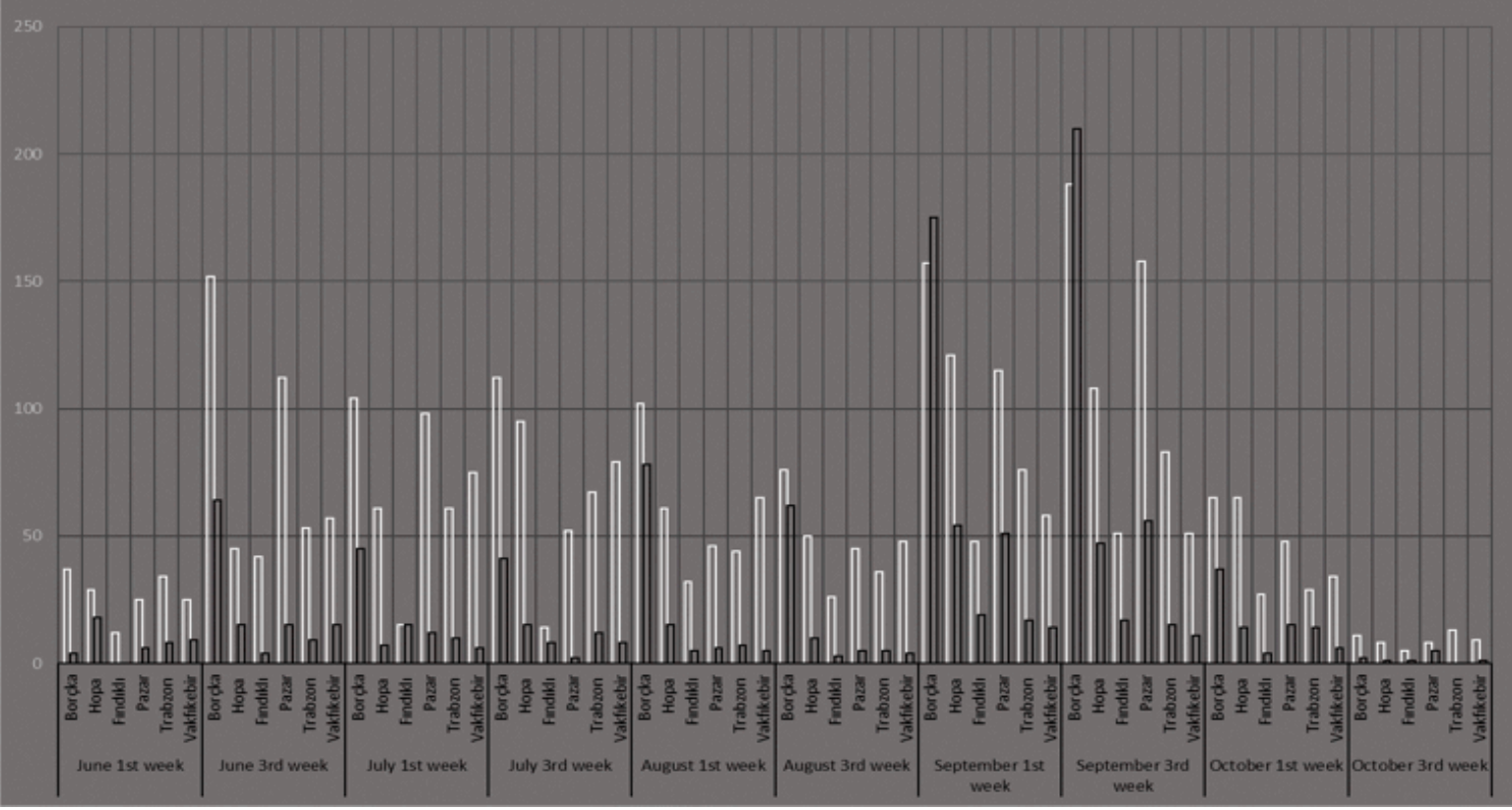

Figure 2. Population fluctuations of the Aedes albopictus in the 2016 active vector season without control operations

2017

DAedes albopictus lannae $\quad$ a Aedes albogictus adult

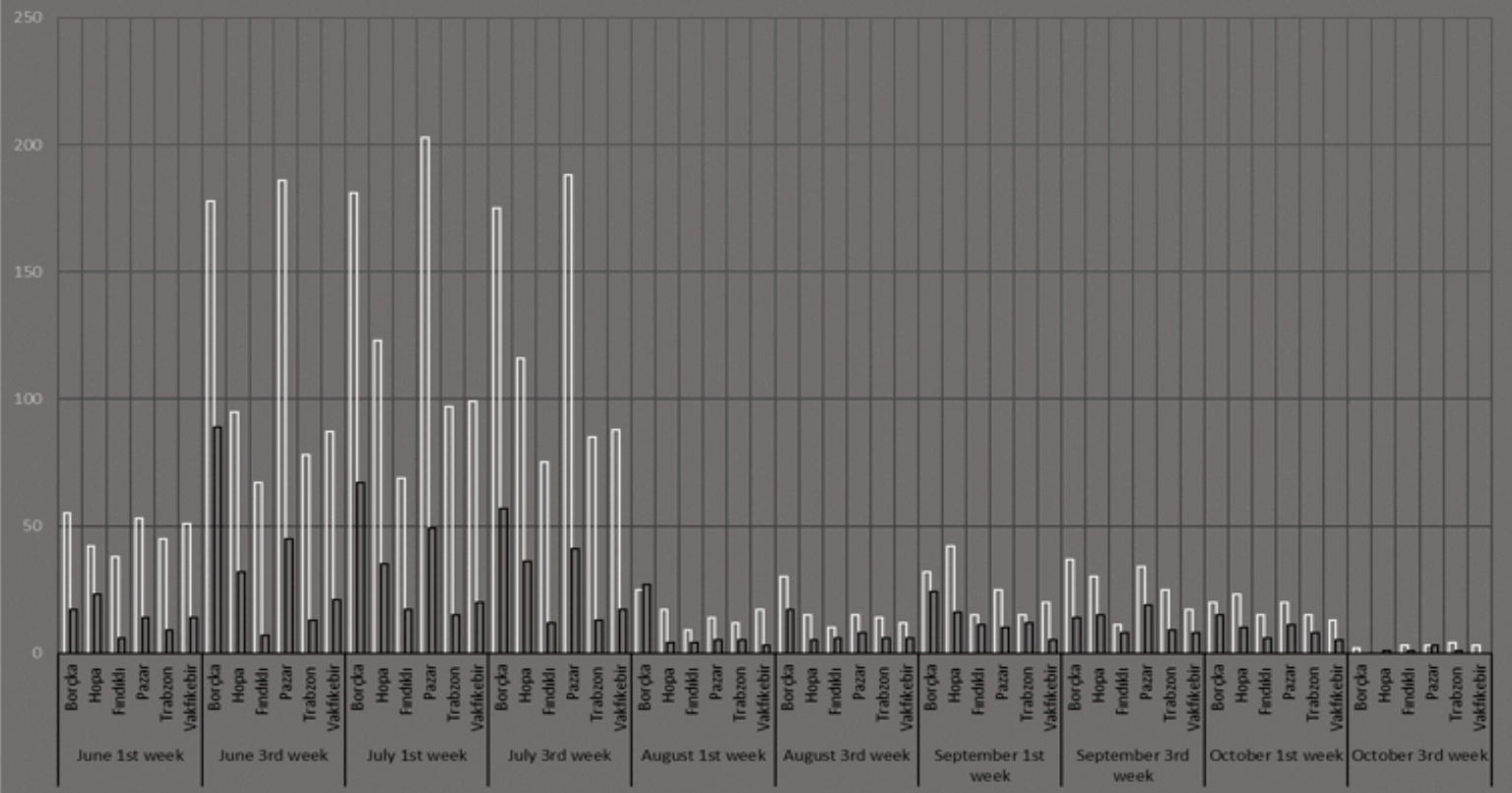

Figure 3. Population fluctuations of the Aedes albopictus in the 2017 active vector season without control operations 
densities were neither high nor correlated with larval densities.

Larval densities varied greatly for Ae. aegypti during June and July and were higher than the densities of 2016. In contrast to Ae. albopictus, Ae. aegypti increased again in October (Fig. 5). Larval density reductions varied 15\%-100\%; however, adult density reductions varied $0 \%-100 \%$ after control applications in August. Additional larvae and adults were found in some places (Hopa, Findıklı and Trabzon) when compared to 2016. Average larval control success was $61 \%$, and adult control operations

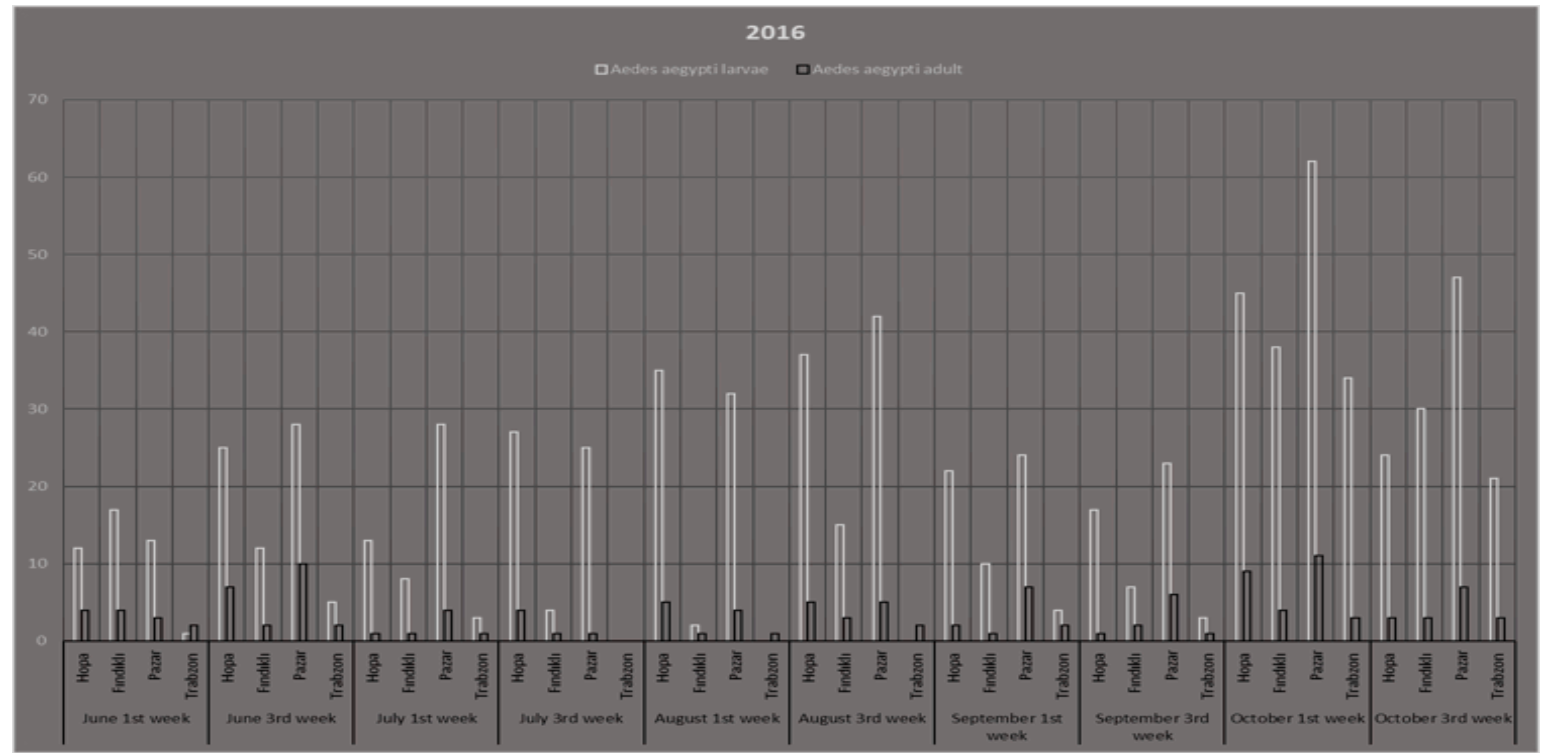

Figure 4. Population fluctuations of the Aedes aegypti in the 2016 active vector season without control operation

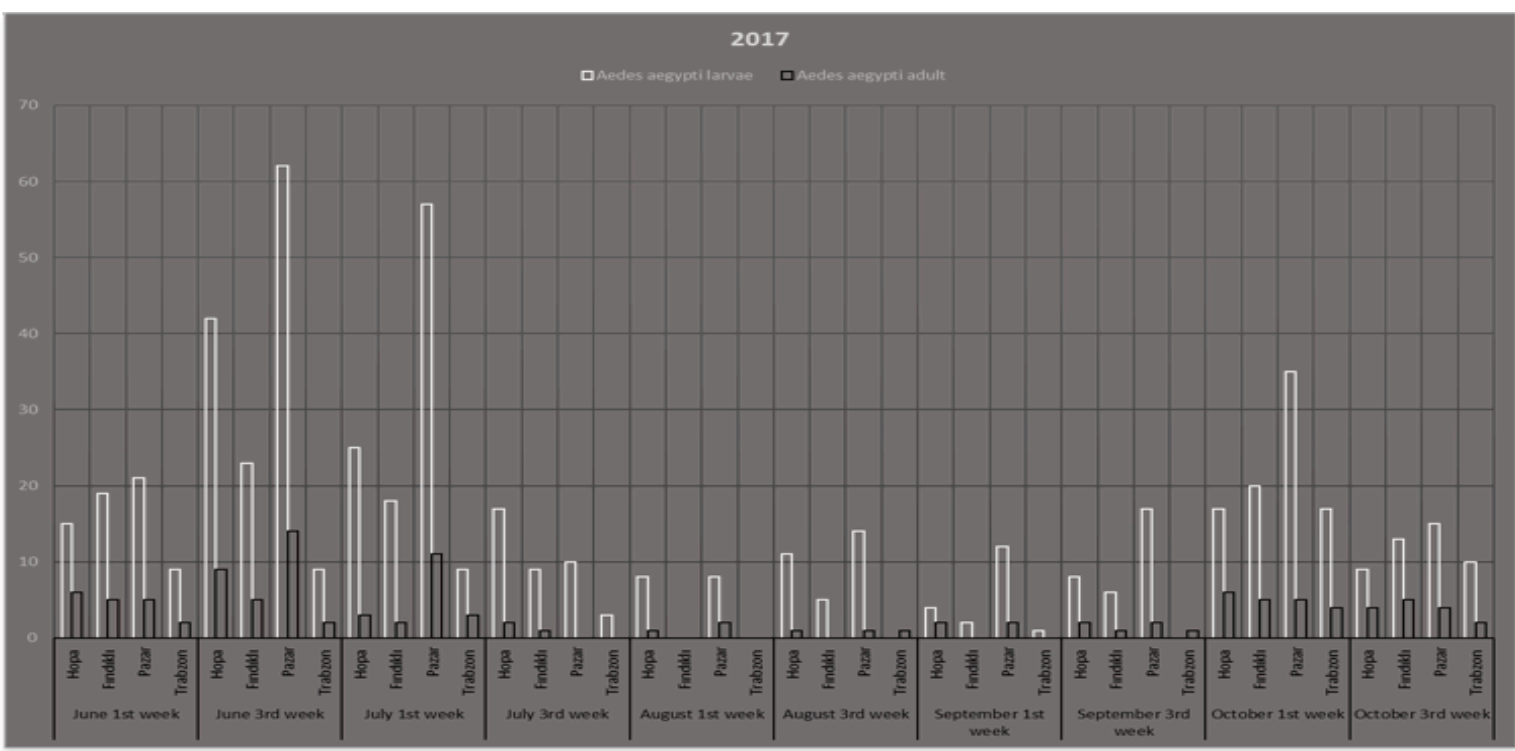

Figure 5. Population fluctuations of the Aedes aegypti in the 2017 active vector season with and without control operations 
success was $37 \%$ for all areas throughout the season.

\section{DISCUSSION}

Mosquitoes can cause serious threats to human and animal health attributable to their vectorial capacity. Both the Asian tiger mosquito and the yellow fever mosquito have become a significant concern due to their seemingly uncontrollable expansion and their many risks to public health. Four significant infections transmitted by $A e$. albopictus and Ae. aegypti: dengue, yellow fever, chikungunya, and Zika virus, lead to observable consequences, such as morbidity, mortality, and healthcare expenditure, in low and middle-income countries (26). In addition to the diseases mentioned above, these Aedes mosquito species can be a vector of endemic viral infections such as West Nile Virus infection (WNV), Mayoro virus infection, and Eastern Equine Encephalitis virus infection (27-29).

Turkey is currently at risk for arboviral diseases such as West Nile fever, dengue, and yellow fever. West Nile virus was first detected in domestic animals (30); the first human cases were ascertained in 1977 (31). Several times antibodies to WNV have been detected in animals and humans (32-33). In 2010, the WNV infection was detected in 47 individuals and 10 of these patients perished (34). Human dengue virus antigens were first detected in 1980 (35-36). Dengue virus antigens have been identified in blood donors from central Anatolia. Yellow fever has not been reported in Turkey, but anti-YFV antibodies were reported in 1980 (35). Currently, YFV-IgGs antibodies have been detected in the sera (36). Although autochthonous chikungunya cases have not been reported in Turkey, imported chikungunya cases from New Delhi were detected in 2012 (37).

Due to the above risks, and for any other unknown arboviral disease risks, there was an urgent need for a surveillance study and control actions against the established populations in the Eastern Black Sea area. Here, we surveyed the invasive species presence, persistence and expansion in three cities in which they were first detected in 2015. Secondly, we gauged the annual population fluctuations prior to and following all control activities.

In 2016, a surveillance study was conducted and locations were described in terms of the presence of Ae. albopictus and Ae. aegypti in well-established populations. The last spread point for the $A e$. albopictus invasion was in Espiye-Giresun and the Ae. aegypti's was in Trabzon. Some districts, such as Kemalpaşa, Borçka, and Vakfıkebir, contain new larval breeding areas. Larvae and adults were detected in every possible area within these districts. These results revealed that the dispersion and newly established populations were around the first discovered locations; in addition, these populations were continuing to spread to other districts and cities. This dispersion and establishment was possibly affected by factors such as climate, land usage, and waste tire usage. Population fluctuations revealed the considerably high population areas in 2016. Populations displayed a bimodal structure and the first peak was determined to be in the end of June while the second and largest peak was identified to be in September. Densities were stable or relatively less so during the six week period from the last week of July to the end of August. Ae. aegypti wellestablished populations were found lower than those of Ae. albopictus, but was generally in the same area as Ae. albopictus. Furthermore, population densities were lower than the Aedes albopictus and exhibited a rising trend from the beginning to the end of the active season. Ae. albopictus densities had two peaks and decreased from the first peak to the second peak. Ae. aegypti had one peak towards the end of the active season wherein Aedes albopictus densities were low. Furthermore, densities were relatively high between the two peak periods of Ae. albopictus. This can be explained as competition between the two species. Jansen and 
Beebe (38) determined this, and they revealed that Ae. aegypti distribution and density was affected by the invasion of Ae. albopictus in the United States.

Well-established populations in three cities and their districts were determined in 2017. Many areas had well-established populations, 194 points in three cities and districts, in the initial part of the surveillance study, prior to control operations. This can be linked to the population movement within Turkey and the bordering areas with Georgia and human activity in these areas. Population movement at the Sarp border was more than 20,000 people per day during the active season. Local human movement in the areas is higher due to tea harvesting and other agricultural facilities. These correlate with the global expansion of the Ae. albopictus; its chaotic dispersion is facilitated by human activity (39). Larvae were discovered in most larval development areas in 2017, for instance, inside used tires, plastic containers, cans, buckets, and puddles; in contrast, in 2015 and 2016, larvae were found in some larval development areas and only inside used tires and waste plastic cups. Different studies indicated that Ae. albopictus is able to tolerate climatic conditions that differ from its native range and is able to use different larval habitats (40-41). Climatic conditions and rainfall regimes of the Eastern Black Sea area are unlike other areas of Turkey. This factor fostered an extension of the active season and the formation of new potential larval breeding sites.

Control operations with different larvicides and adulticides commenced in the third week of July. Control operations began with the application of pyriproxyfen (IGR) throughout the entire area. At the same time, two different adulticides, Cypermethrin+tetramethrin+PBO and Geraniol, were applied to reduce adult population levels. In the second month, larval control continued with the application of Bti+Bs, granular formulation, and liquid Bti formulations. Adult control continued with employing imidaclobrid+lambda cyhalothrin formulations (in Artvin) and Cypermethrin+tetramethrin+PBO formulations (throughout the entire area). Only liquid Bti formulation was utilized for larval control in all areas; adult control was accomplished with imidacloprid+lambda cyhalothrin (in Artvin), Cypermethrin+tetramethrin+PBO, and cyfluthrin+tetramethrin+PBO formulations in September. Larval control reduced larval densities by an average of $69 \%$; whereas adult control reduced adult densities by $46 \%$ in all areas during the season for Ae. albopictus. Climatic conditions and rainfall regimes in the study area affected the control facilities and reduced control success. The same situation was observed in Ae. aegypti control. Larval reduction was determined as $61 \%$, and adult reduction was calculated as $37 \%$. Control success was also linked to used tire storage area conditions and storage patterns. With the application of formulation of pyriproxyfen briquettes, larval control operations were found to be highly effective in the first two weeks; but, in order to reduce the risk of insecticide resistance development, the larvicide was changed to Bti and Bs combination or liquid Bt in the third week. We chose to use Bti and Bs combination or liquid Bti for larval control operations after pyriproxyfen in order to avoid resistance risk and cross resistance related to the detoxification mechanisms of pyriproxyfen which leads to a reduction in efficacy. Pyriproxyfen resistance was described in some Ae. albopictus strains in Florida and New Jersey (42). Both Andrighetti et al. (43), and Marcombe et al. (44) described temephos resistance and less susceptibility to pyriproxyfen in Ae. aegypti and implied a possible cross resistance between the two insecticide groups in mosquitoes.

Adult control was achieved primarily by the usage of pyrethroid based insecticides and secondarily with a nicotine mimic insecticide combination with pyrethroid. Adult control success was under $50 \%$ for the two species. Adult control in the used tire storage area could not be performed 
properly as the insecticide could not be effectively applied throughout the entire area. Therefore, a low level of success in adult control was achieved. Another factor that impeded success was insecticide usage restrictions in the areas near larval breeding sites. The Turkish government prohibits the use of chemical based insecticides in the vicinity of tea plantations. Therefore, we applied insecticides to limited areas around larval breeding sites. Adults avoided contact with insecticides during operations by fleeing to agricultural areas. Merely one ultra-low volume adulticides, Geraniol, was used in crop areas. Other adulticides were used alternately during the operations due to an insecticide resistance risk.

Repeatedly the use of pyrethroids has increased the resistance levels of mosquitoes. In adults of Ae. aegypti and Ae. albopictus, resistance levels to pyrethroids are generally lower in Asia, Africa and the USA, but higher in Latin America (45). The resistance of these two species has not yet been defined for this area, although many areas in the Middle and Eastern Black Sea region include resistance populations of $C x$. pipiens complex species (46). Therefore, it is essential to annually assess the resistance status of these species to different classes of insecticides.

In conclusion, this study revealed the rapidly expanding distribution range and high population density of two invasive mosquito species in the invasion areas. Control operations success was achieved at $60 \%$ for larvae and at approximately $45 \%$ for adults. This level of control success may be ascribed to several factors, but the primary factor is due to area conditions and climatic variations in association with rainfall regimes. Rainfall regimes can significantly affect an insecticide's efficacy. Therefore, an urgent strategic plan is essential for integrated control strategies. Integrated control strategies combine chemical, physical, biological, and cultural control measures (22). WHO also recommends Integrated Vector Management (IVM), the aim of which is to improve the cost-effectiveness, ecological soundness and sustainability of diseasevector control (47). Therefore, it is crucial to monitor and evaluate during and after the implementation of control measures (22).

\section{REFERENCES}

1. European Centre for Disease Prevention and Control (ECDC). Guidelines for the surveillance of invasive mosquitoes in Europe. Technical Report. Stockholm; ECDC, 2012.

2. Adhami J, Reiter P. Introduction and establishment of Aedes (Stegomyia) albopictus Skuse (Diptera: Culicidae) in Albania. J Am Mosq Control Assoc, 1998; 14: 340-3.
3. Sabatini A, Raineri V, Trovato G, Coluzzi M. Aedes albopictus in Italy and possible diffusion of the species into the Mediterranean area. Parassitologia, 1990; 32 (3): 301-4.

4. Medlock JM, Hansford KM, Schaffner F, et al. A review of the invasive mosquitoes in Europe: ecology, public health risks, and control options. Vector Borne Zoon Dis, 2012; 12: 435-47. 
5. Oter K, Gunay F, Tuzer E, Linton YM, Bellini R, Alten B. First record of Stegomyia albopicta in Turkey determined by active ovitrap surveillance and DNA barcoding. Vector Borne Zoon Dis, 2013; 13 (10): 753-61.

6. Akiner MM, Demirci B, Babuadze G, Robert V, Schaffner F. Spread of the Invasive Mosquitoes Aedes aegypti and Aedes albopictus in the Black Sea Region Increases Risk of Chikungunya, Dengue, and Zika Outbreaks in Europe. Plos Negl Trop Dis, 2016; 10 (4): e0004664.

7. Jentes ES, Poumerol G, Gershman MD, Hill DR, Lemarchand J, Lewis RF, Staples JE, Tomori O, Wilder-Smith A, Monath TP. Informal WHO Working Group on Geographic Risk for Yellow Fever. 2011. The revised global yellow fever risk map and recommendations for vaccination, 2010: consensus of the informal WHO Working Group on Geographic Risk for Yellow Fever. The Lancet Infectious Diseases, 2011; 11: 622-32.

8. Simmons CP, Farrar JJ, Chau NVV, Wills B. Dengue. The New England Journal of Medicine, 2012; 366: 1423-32.

9. Wong PSJ, Li MZI, Chong CS, Ng LC, Tan CH. Aedes (Stegomyia) albopictus (Skuse): a potential vector of Zika virus in Singapore. Plos Negl Trop Dis, 2013; 7: e2348.

10. Collantes F, Delacour S, Alarcón-Elbal PM, RuizArrondo I, Delgado JA, Torrell-Sorio, A, et al. Review of ten-years presence of Aedes albopictus in Spain 2004-2014: known distribution and public health concerns. Parasit Vectors, 2015: 8, 655.

11. Roiz D, Neteler M, Castellani C, Arnoldi D, Rizzoli A. Climatic factors driving invasion of the tiger mosquito (Aedes albopictus) into new areas of Trentino, northern Italy. Plos ONE, 2011; 6: e14800.

12. Rochlin I, Ninivaggi DV, Hutchinson ML, Farajollahi A. Climate change and range expansion of the Asian tiger mosquito (Aedes albopictus) in Northeastern USA: implications for public health practitioners. Plos ONE, 2013; 8: e60874.
13. Benedict MQ, Levine RS, Hawley WA, Lounibos LP. Spread of the tiger: Global risk of invasion by the mosquito Aedes albopictus. Vector Borne Zoon Dis, 2007; 7: 76-85

14. Enserink M. A mosquito goes global. Science, 2008; 320: 864-6.

15. Schaffner $F$, Mathis A. Dengue and dengue vectors in the WHO European Region: past, present, and scenarios for the future. Lancet Infect Dis, 2014; 14 (12): 1271-80.

16. Brown JE, Evans BR, Zheng W, Obas V, BarreraMartinez L, Egizi A, Zhao H, Caccone A, Powell JR. Human impacts have shaped historical and recent evolution in Aedes aegypti, the dengue and yellow fever mosquito. Evolution, 2014; 68:514-25.

17. Brown JE, McBride CS, Johnson P, Ritchie S, Paupy $\mathrm{C}$, Bossin $\mathrm{H}$ et al. Worldwide patterns of genetic differentiation imply multiple 'domestications' of Aedes aegypti, a major vector of human diseases. Proc Biol Sci, 2011; 278:2446-54.

18. Yunicheva YU, Ryabova TE, Markovich NY, Bezzhonova OV, Ganushkina LA, Semenov VB, et al. First data on the presence of breeding populations of the Aedes aegypti L. mosquito in Greater Sochi and various cities of Abkhazia. Meditsinskaia Parazitologiia I Parazitarnye Bolezni, 2008; 3: 403.

19. Scholte E, Den Hartog W, Dik M, Schoelitsz B, Brooks M, Schaffner F, et al. Introduction and control of three invasive mosquito species in the Netherlands, July October 2010. Euro Surveill, 2010; 15 (45): 19710.

20. European Centre for Disease Prevention and Control (ECDC). Zika virus disease epidemic: preparedness planning guide for diseases transmitted by Aedes aegypti and Aedes albopictus. Stockholm; 2016.

21. WHO, 2017. Dengue control. The mosquito [online]. Available from: http://www.who.int/ denguecontrol/mosquito/en/. 
22. European Centre for Disease Prevention and Control (ECDC). Vector control with a focus on Aedes aegypti and Aedes albopictus mosquitoes: literature review and analysis of information. Stockholm; 2017.

23. Van den Berg H, Velayudhan R, Ejov M. Regional framework for surveillance and control of invasive mosquito vectors and re-emerging vector-borne diseases 2014-2020. Copenhagen; World Health Organization, 2013.

24. WHO. The long road to malaria elimination in Turkey. (Eliminating malaria case-study, 5), 2013.

25. URL 1. Surveillance and Control of Aedes aegypti and Aedes albopictus in the United States https:// www.cdc.gov/chikungunya/pdfs/Surveillanceand-Control-of-Aedes-aegypti-and-Aedesalbopictus-US.pdf.

26. Weeratunga P, Rodrigo C, Fernando SD, Rajapakse S. Control methods for Aedes albopictus and Aedes aegypti. Cochrane Database of Systematic Reviews 2017; 8: CD012759.

27. Daep CA, Muñoz-Jordán JL, Eugenin EA. Flaviviruses, an expanding threat in public health: focus on dengue, West Nile, and Japanese encephalitis virus. J Neurovirology, 2014; 20 (6): $539-60$.

28. Long KC, Ziegler SA, Thangamani S, Hausser NL, Kochel TJ, Higgs $S$, et al. Experimental transmission of Mayaro virus by Aedes aegypti. American J Trop Med Hyg, 2011; 85 (4): 750-7.

29. Romero JR, Newland JG. Viral meningitis and encephalitis: traditional and emerging viral agents. Sem in Ped Infec Dis, 2003; 14 (2): 72-82.

30. Radda, A. Antibodies against group A and B Arboviruses in domestic animals from Turkey. EU Tip Fak Mec, 1971; 10: 227-30.

31. Ari A. Studies on activity and ecology of arboviruses in Turkey. Turk Hij Den Biyol Derg, 1972; 32: 13443.
32. Ergunay K, Ozer N, Us D, Ozkul A, et al. Seroprevalence of West Nile virus and TickBorne Encephalitis virus in Southeastern Turkey: first evidence for Tick-Borne Encephalitis virus infections. Vector Borne Zoon Dis, 2007; 7: 157 161.

33. Ergunay K, Saygan MB, Aydogan S, Menemenlioglu $D$, et al. West Nile virus seroprevalence in blood donors from Central Anatolia, Turkey. Vector Borne Zoon Dis, 2010a; 10: 771-5.

34. Kalaycioglu H, Korukluoglu G, Ozkul A, Oncul O, Tosun S, Karabay O, et al. Emergence of West Nile virus infections in humans in Turkey, 2010 to 2011. Euro Surveill, 2012; 17 (21): 20182.

35. Serter, D. Present status of arbovirus seroepidemiology in the Aegean region of Turkey. In: Vesenjak-Hirjan, J, Porterfield, JS, Arslanagic, E, eds. Arboviruses in the Mediterranean Countries. Stuttgart, New York: Gustav Fisher Verlag, 1980: 155-61.

36. Ergunay K, Saygan MB, Aydogan S, Litzba N, et al. Investigation of Dengue virus and Yellow Fevers virus exposure in blood donors from Central/ Northern Anatolia, Turkey. Microbiology Bull, 2010b; 44: 413-22.

37. Çağlayık DY, Uyar Y, Korukluoğlu G, Ertek M, Unal S. An Imported Chikungunya Fever Case from New Delhi, India to Ankara, Turkey: The First Imported Case of Turkey and Review of the Literature. Microbiology Bull, 2012; 46 (1): 122-8.

38. Jansen CC, Beebe NW. The dengue vector Aedes aegypti: what comes next? Microbes Infect, 2010; 12 (4): $272-9$

39. Manni M, Gomulski LM, Aketarawong N, Tait G, Scolari F, Somboon P, et al. Molecular markers for analyses of intraspecific genetic diversity in the Asian Tiger mosquito, Aedes albopictus. Parasit Vectors, 2015; 8: 188. 
40. Costanzo KS, Schelble S, Jerz K, Keenan M. The effect of photoperiod on life history and bloodfeeding activity in Aedes albopictus and Aedes aegypti (Diptera: Culicidae). J Vector Ecol, 2015; 40 (1): 164-71.

41. Brady OJ, Golding N, Pigott DM, Kraemer MUG, Messina JP, Reiner RC, et al. Global temperature constraints on Aedes aegypti and Ae. albopictus persistence and competence for dengue virus transmission. Parasit Vectors, 2014; 7 (338): 1-17.

42. Marcombe S, Farajollahi A, Healy SP, Clark GG, Fonseca DM. Insecticide Resistance Status of United States Populations of Aedes albopictus and Mechanisms Involved. Plos ONE, 2014; 9 (7): e101992.

43. Andrighetti MTM, Cerone F, Rigueti M, Galvani KC, Macoris MdLdG. Effect of pyriproxyfen in Aedes aegypti populations with different levels of susceptibility to the organophosphate temephos. Dengue Bull, 2008; 186-98.
44. Marcombe S, Darriet F, Agnew P, Etienne M, Yp-Tcha $M M$, et al. Field efficacy of new larvicide products for control of multi-resistant Aedes aegypti populations in Martinique (French West Indies). American J Trop Med Hyg, 2011; 84: 118-26.

45. Smith LB, Kasai S, Scott JG. Pyrethroid resistance in Aedes aegypti and Aedes albopictus: Important mosquito vectors of human diseases. Pest Biochem and Physiol, 2016; 133: 1-12.

46. Akıner MM. Insecticide Resistance of the Culex pipiens complex species (Diptera: Culicidae distributed in the Middle and East Blacksea Regions of Turkey. Turkish Scientific Council Project report (113Z795), 2017.

47. WHO. Global strategic framework for integrated vector management. World Health Organization, Geneva; 2004. 